
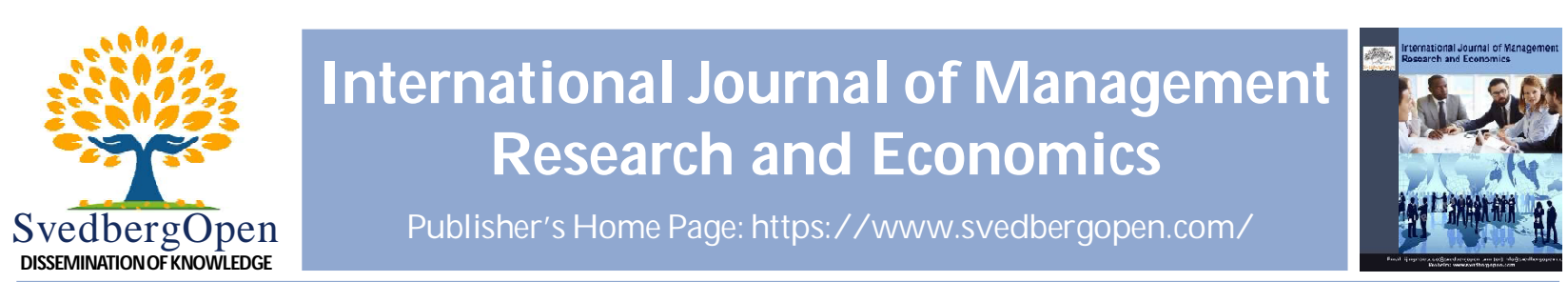

\title{
The effect of the Ebola Virus Disease on intra-regional trade in West Africa
}

Abban, Stanley ${ }^{*}$

${ }^{1}$ Kwame Nkrumah University of Science and Technology, Accra Rd, Kumasi, Ghana. E-mail: stanicorn@yahoo.com

\begin{tabular}{|c|c|}
\hline Article Info & $\begin{array}{l}\text { Abstract } \\
\text { The West African sub-region experienced the World's largest Ebola outbreak after its maiden } \\
\text { outbreak in Central Africa. In this background, economic activities were heavily affected } \\
\text { hence intra-regional trade shares of affected countries. Given this, the study seeks to }\end{array}$ \\
\hline $\begin{array}{l}\text { Volume 1, Issue 2, April } 2021 \\
\text { Received : } 07 \text { December } 2020 \\
\text { Accepted : } 17 \text { March } 2021 \\
\text { Published : } 05 \text { April } 2021 \\
\text { doi: } 10.51483 \text { /IJMRE.1.2.2021.18-32 }\end{array}$ & $\begin{array}{l}\text { investigate the effect of the Ebola Virus Disease (EVD) on affected countries shares to } \\
\text { Community of West African States (ECOWAS) membership on trade in West Africa. The } \\
\text { Poisson Pseudo Maximum Likelihood (PPML) was used to estimate the augmented gravity } \\
\text { model of international trade. The results showed that the EVD reduced the share of affected } \\
\text { countries' trade to intra-regional partners by two folds. Also, the study showed that } \\
\text { ECOWAS membership doubles the level of trade. The study concludes that the ECOWAS } \\
\text { should be proactive in their response to disease outbreak by investing in research. Additionally, } \\
\text { the study shows that Mauritania will benefit from opting for the ECOWAS. } \\
\text { Keywords: Ebola Virus Disease (EVD), Poisson Pseudo Maximum Likelihood (PPML), } \\
\text { ECOWAS, Gravity model of international trade } \\
\text { ( } 2021 \text { International Journal of Management Research and Economics. This is an open access article } \\
\text { under the CC BY license (https://creativecommons.org/licenses/by/4.0/), which permits unrestricted } \\
\text { use, distribution, and reproduction in any medium, provided you give appropriate credit to the original } \\
\text { author(s) and the source, provide a link to the Creative Commons license, and indicate if changes were made. }\end{array}$ \\
\hline
\end{tabular}

\section{Introduction}

The Ebola Virus Disease (EVD), formerly Ebola hemorrhagic fever is a severe and fatal illness with a mortality rate of 25\%90\% (Etuk, 2015; Tseng and Chan, 2015; Bell et al., 2016). The virus is primarily transmitted to humans through contact with bodily fluids of infected animals and secondarily through humans. These include contact with blood, mucus, saliva, vomit, sweat, fever, urine, breast milk, semen, vaginal secretions, feces, deceased body, urine of recovered patient among others (Centers for Disease Control and Prevention (CDC), 2014; Baize et al., 2014; WHO, 2018; ILO, 2018). The virus invasion in humans appears to occur through mucosal surfaces, breaks, and abrasions in the skin, or parenteral introduction (Alexander et al., 2015; Madariaga, 2015). The Ebola virus, which is a zoonotic pathogen virus, was reported to be harbored in bush meats notably fruit bat of the family Pteropodidae, with early cases of infection reported in the rural areas (Madariaga, 2015; Kadanali and Karagoz, 2015; Judson et al., 2016). The symptomatology of the disease is like many other diseases, such as malaria, internal bleeding, external bleeding, intense weakness, Lassa fever, extreme fatigue, muscle pains, dizziness, headache, diarrhea, skin rash, sore throat, impaired kidney, cholera, influenza and typhoid among others, with an incubation period of 2-21 days (Woldemariam and Di Giacomo, 2016). The symptoms were corollary to the high body temperature of the infected persons, about $38^{\circ} \mathrm{C}\left(100.4^{\circ} \mathrm{F}\right)$. The five species of the Ebola virus, which originates from the family Filoviridae, have been pinpointed by the World Health Organization (WHO), notably the Zaire ebolavirus, Sudan ebolavirus, Taï Forest ebolavirus, Reston ebolavirus (which has caused asymptomatic

\footnotetext{
* Corresponding author: Abban, Stanley, Kwame Nkrumah University of Science and Technology, Accra Rd, Kumasi, Ghana.

E-mail: stanicorn@yahoo.com
} 
infections in humans but disease in nonhuman primates only) and Bundibugyo ebolavirus (Madariaga, 2015; Bell et al., 2016; Singh et al., 2017). In Africa, the causative viruses were the Zaire ebolavirus, Sudan ebolavirus, and Bundibugyo ebolavirus. The measures taken to curb the outbreak were to wash hands frequently with soap and water, the use of alcohol-based hand sanitizer, the use of disinfectants on public shared facilities, isolation of infected persons, and contact tracing, screening and the practice of social distancing from sick people as recommended of Doctors Without Borders / Médecins Sans Frontières (MSF). More so, the infected patients were advised to stay home as an initial remedy to reduce spread, avoid the use of public transports, seek urgent medical assistance, and adhere to guidelines from medical experts which has been used to curb over 20 outbreaks as well as ensure the safe transportation of infected persons (Kalra et al, 2014; Isakov et al, 2015; Woldemariam and Di Giacomo, 2016; Bell et al., 2016; WHO, 2018; ILO2018).

The traditional niche of the EVD on the African continent can be traced to Central Africa notably Yambuku in Zaire (now the Democratic Republic of Congo) and Nzara, South Sudan in 1976 (Peters and LeDuc 1999; Heymann et al. 1999; Kerstiëns and Matthys 1999; Rosello et al. 2015; Breman et al.2016). The first case was reported in a village near the Ebola River in Zaire which influenced the name of the causative virus (Kalra et al, 2014; Kadanali and Karagoz, 2015). The devastating nature of the disease accounted for a mortality rate of $88 \%$ and $66 \%$ respectively during its maiden outbreak in Zaire and Nzara (Adegun, 2014). In the year 1995, the disease resurfaced in the Democratic Republic of Congo, which claimed numerous lives including medical professionals, and exposed the vulnerability in the governance and health sector of the economy (Rupavate S, 2014 cited by Adegun (2014); Wagenaar et al, 2018). Since then, traces of the deadly disease was prevalent in the Democratic Republic of Congo, Sudan, Gabon, Congo, South Sudan, and Uganda, with a median of three outbreaks per year and over 30 outbreaks with a death toll close to 1600 (Salaam-Blyther, 2014). Most Ebola-stricken countries were on the back of prolonged civil wars so the disease posed a greater threat to the health sector (Kaasik-Aaslav et al., 2015; Ribacke et al, 2015).

On December 6, 2013, West Africa was hit with the index case in Guéckédou, Guinea, involving the death of a 2-yearold child (Joshi, 2014; Burd, 2015). The child came in contact with the virus while playing near an infected bat according to Robert Koch Research Institute in Berlin. Consequently, similar symptoms were experienced in his mother, sister, and grandmother which led to their demise. Then close contacts began to experience the symptoms and the outbreak began spreading its tentacles to neighboring villages. Surprisingly, the outbreak had spread wide to neighboring countries of Sierra Leone and Liberia (Kramer et al, 2016). As a result, the WHO, the primary body superintended to work out and execute the 2005 International Health Regulations (IHR), was notified on March 21, 2014 by Guinea, followed by Liberia on March 30 and Sierra Leone on May 25. The WHO confirmed the disease to be EVD ingrained in empirical research. In the analysis of Kamradt-Scott (2014), the late response of the WHO to the Ebola outbreak was an attributing factor to the spread of the disease.

Nigeria experienced the EVD with the arrival of an infected air traveler from Liberia to Lagos on July 20, 2014, and initiated the spread (Fasina et al., 2014; Shuaib et al., 2014; Althaus et al, 2015). Similarly, a university student infected with the EVD evaded health surveillance for weeks as he travelled to Senegal from Guinea, by road.

The outbreak was officially declared as a Public Health Emergency of International Concern (PHEIC) on August 8, 2014, under the aegis of the 2005 IHR as reported by Reuters, since the WHO estimate the true prevalence to be two to four times higher than the reported figures and the potential of spreading to the international community according to US health authorities and MSF. To buttress, data collection challenges on virus-contracted persons based on responses from correspondents and laboratory staff indicated under-reported cases (Owada et al, 2016; Cori et al, 2017). In response, the Global Alert and Response Network (GOARN) under the auspices of the WHO, and the US Center for Disease Control and Prevention (CDC) deployed a team to complement national efforts toward infection prevention and control (IPC) to extirpate transmission (Mobula et al, 2018). Also, there was a coordinated international effort to activate a Travel and Tourism Taskforce to provide documentation about the travel and tourism sector along with travelers (WHO, 2014; Maphanga, 2019). The failure of independent countries to contain the virus led to the collaborative efforts of the Economic Community of West African States (ECOWAS), Mano River Union (MRU), the West African Health Organization (WAHO) under the auspices of the ECOWAS Commission, Health Ministers of States, the African Union Support to Ebola Outbreak in West Africa (ASEOWA) under the auspices of the African Union, private sector partnership of telephone operators namely MTN, Etisalat and Airtel, The African Center for Disease Control and Prevention (ACDCP), the Ministers of Health of West Africa and the Head of State and Government (HoS\&G) which mobilized political and social backing to fight the virus. As a precautionary measure, neighboring West African countries to the infected countries closed their borders conspicuously Ivory Coast Senegal, Chad among other West African countries, closed their borders with Liberia, Sierra Leone, Guinea, and Nigeria. Air travels were the predominant means of the EVD spread internationally (Bogosh et al., 2014; Gomes et al., 2014). This led to the cancellation of flights to Guinea, Liberia, and 
Sierra Leone notably from Kenya, South Africa, Ethiopia, Argentina, Brazil, China, Panama, Chile, among others (Ferrel and Agarwal, 2018). According to the Official Airline Guide (OAG), of 590 monthly flights scheduled to Guinea, Liberia, and Sierra Leone, 216 have been cancelled. The Guardian reported that Air Côte d'Ivoire, Nigeria's Arik Air, Togo's ASKY Airlines, British Airways, Emirates Airways, and Kenya Airways cancelled a combined 76 scheduled flights to Guinea, 70 to Liberia, and 70 to Sierra Leone which harmed international trade. Other countries that recorded cases were Mali, Italy, Spain, Germany, the United Kingdom, and the United States of America (Goeijenbier et al., 2014). The WHO issued a regional plan, asking the international community to fill a $\$ 71 \mathrm{mn}$ gap, the first in a succession of rising cost estimates, reaching $\$ 988 \mathrm{mn}$ in a UN appeal in mid-September. However, controversy arose over the ethical allocation of therapies after several Americans and a Spanish national, rather than West Africans, received doses of the scarce ZMapp, an experimental biopharmaceutical (Gostin and Friedman, 2015). Donor countries and organization came to the aid which includes the United States of America ( $\$ 937 \mathrm{mn})$, the United Kingdom ( $\$ 330 \mathrm{mn})$, Germany $(\$ 172 \mathrm{mn})$, the World Bank (\$137 mn), and France (\$108 mn), as of 17 February 2015 (UNDG-WCA, 2015). Also, the United Nations Mission for Ebola Emergency Response (UNMEER) contributed \$1 bn for Overall Needs and Requirements (ONR) as of December 8, 2014 (United Nations Office for the Coordination of Humanitarian Affairs, 2014a; Grépin, 2015). The large aid inflows cushioned the fiscal space even though expenditure rose abruptly which culminated to $8.7 \%$ in Liberia, $5.4 \%$ in Sierra Leone, and $1.3 \%$ in Guinea in 2015 (World Bank, 2016).

This was the World's largest Ebola outbreak due to its uniqueness in size, complexity, duration, morbidity, and coverage. It was the $25^{\text {th }}$ known EVD since the first outbreak in 1976 and affected 10 countries in three continents (Centers for Disease Control and Prevention (CDC), 2014; Ajisegiri et al., 2018). The World Bank estimated that potentially catastrophic consequences may cost up to $\$ 25$ bn and likely to cost about $\$ 32.6$ bn by the end of 2015 (WBG, 2014a; Bell et al., 2016). The spread began in the rural area to the more dense urban centers of countries characterized by a high poverty rate coupled with poor infrastructure and institutional settings (Malvy et al, 2019). On December 29, 2014, more than 20,000 infections have been reported with a death toll of 7,900. In June 2015, the WHO announced a total of 22,000 children who lost either one or both parents due to the EVD (UNDG-WCA, 2015). According to the WHO, 4,809 deaths were recorded in Liberia, 3,955 deaths were recorded in Sierra Leone, 2,536 deaths in Guinea, 8 deaths recorded in Nigeria and 6 deaths in Mali culminating in a total death counts of 11,314.

On average, the mortality rate of infected persons was estimated to be $60 \%$ and mortality per capita was estimated to be 5 per 10,000 for affected countries (World Bank, 2016). The factors that led to the wide-spread was the fragility of the health sectors, home treatment of infected persons, vulnerabilities from past civil wars, social values and structures such as relatively large size funeral rites, greeting, hugging, shaking of hands as well as touching, washing and arranging bodies for burial were rituals ingrained in the culture of Africans, damaged ecological system due to the extractive industry, and inadequate resources deployed in the diagnosis and treatment of infected persons (CDC, 2014; Kalra et al, 2014; Woldemariam and Di Giacomo, 2016; Ajisegiri et al., 2018). In this background, the distrust of government and medical doctors by indigenes was based on the pretense of wrongful diagnose of common illnesses and an acclaimed purported strategy by the government to induce foreign aid (Gostin and Friedman, 2015). The governments were illequipped to contain the spread due to corruption, and a lack of timely aid from the international community. As a result, it led to the protest of citizens against the legitimacy of government actions and accusation of misappropriated aid (Gostin and Friedman, 2015; Woldemariam and Di Giacomo, 2016; Bell et al., 2016). Also, the spiritual and superstitious connotations attached to the deceased at the early stages exacerbated the widespread of the disease. Furthermore, health workers and journalists that alarmed the upsurging canker were later declared dead notably in Guinea (Pietropaoli et al, 2015; Woldemariam and Di Giacomo, 2016). Additionally, the level of stigmatization attached to the virus- contracted persons discouraged testing and violated their fundamental right to equality and non-discrimination (MSF, 2014b, The Office of the High Commissioner for Human Rights, 2015). Consequently, patients with minor ailment refrained from visiting the medical centers due to fear of contracting the Ebola virus. Also, there were large protests against isolation centers in communities notably Monrovia, Liberia (Woldemariam and Di Giacomo, 2016). In the report, the WHO reported that 401 Health-care workers had contracted the virus with 232 death count by the end of October 5, 2014. This was attributed to the lack of Personal Protective Equipment (PPE) and poor infection control measures deployed such as inadequate sterilization techniques, reuse of needles, equipment among others (Madariaga, 2015). Kramer et al. (2016) showed that the widespread was facilitated by geographical features such as distance, population density, and border relations. To buttress, Woldemariam and Di Giacomo (2016) acknowledged a major causative factor to the porous nature of African borders. Epstein (2014) argued that the spread of the disease was highly political due to relatively poor infrastructure to contain the disease. The EVD was effectively contained in 2016 after its emergence in the West African sub-region. Nigeria and Senegal the first to be declared Ebola-free in October 2014 (WHO, 2014c), with reported 20 cases with 8 deaths and 1 case with no death respectively, followed by Sierra Leone in March 2016 then Guinea and Liberia in 
June. The Journal of Infectious Diseases estimated the societal and economic costs of the epidemic to be $\$ 58$ bn which considered the cost of losing human life, infection control, treatment costs, and death caused by other diseases during the epidemic.

Undeniably, economic activities hitherto trade was brought to an abrupt halt for the most affected countries notably Sierra Leone, Liberia, and Guinea during the epidemic (AfDB, 2020; UNDG-WCA, 2015; Bowles et al, 2016). In effect, Gross Domestic Product (GDP) per capita was averaged at $\$ 125$ per person for the three most affected countries during the pandemic (World Bank, 2016). In 2015, the budget deficits were estimated at 8.5\% of GDP in Liberia, 4.8\% in Sierra Leone, and $9.4 \%$ in Guinea. According to the World Bank, there was a $40 \%$ decrease in the working force. Guinea, Sierra Leone, and Liberia lost $\$ 2.2$ bn in GDP in 2015, with the private sector, agriculture, production, and trade heavily affected. As a result of the measures taken to contain the disease, the supply chain, and operations of both affected and nonaffected countries were affected (British Standards Institution, 2014; Figuiré, 2016). As a result, the EVD disrupted the economy's recovery and limited the progress on the Millennium Development Goals (MDGs) according to the 2015 United Nations Development Group for West and Central Africa (UNDG-WCA) report. In this background, it led to a decline in the per capita income of the three most affected countries (UN, 2014). Guinea was recovering from economic, political, and social crisis since 2011, Liberia had experienced 14 years of civil strife and the recovery of Sierra Leone from a devastating civil war from 1991-2002. The agriculture sector was affected due to restrictions on movement influencing production volumes, relatively tighter exports, and the loss of labor force through death. According to the World Food Programme (WFP), about a million people faced food shortages due to quarantines in the region. In this background, agriculture accounted for 57\% of Sierra Leone's GDP, 39\% of Liberia's, 20\% of Guinea's, and 22\% of Nigeria's GDP according to the Food and Agriculture (FAO). Statistically, the labor force which forms the economically active segment of the population (15-44 years) accounted for 59\% of total infections by the EVD in the phase of the poor health sector.

Also, the mining sector was affected due to disrupted production capacity through the shutdown of operations hitherto informal operations, and financial challenges faced by companies of the status quo notably London Mining, Arcelor Mittal SA, China Union, and Rio Tinto PLC, amidst a fall in the international price of bauxite, iron ore and gold at 30-60\% during the epidemic (World Bank, 2016). Given this, the Ebola epidemic delayed mining projects meant to be filled by thousands of workers in Guinea, Liberia, and Sierra Leone according to the Wall Street Journal. Furthermore, the transport sector was affected which resulted in high transport costs, travel bans, and border closures which harmed tourism due to stigmatization on citizens and the fear of spread (Ajiboye et al, 2015; WHO, 2014, Shultz et al., 2016).

Unconventionally, one major problem that emanated from the spread of the disease was the conflicts between the populace against the traditional leaders, governments, and foreign investors. In this background, the change in the ecological system due to flooding and wildlife resulting from damages caused by extractive companies coupled with relatively small gains generated from these industries to improve living standards of the populace compounded to the spread of the disease (Redding et al, 2019). Also, some countries with no reported cases such as Cape Verde, Ghana, Gambia, Niger, Guinea Bissau, and Togo among others, were affected economically due to fear of possible outbreak notably the hospitality industry, even though stringent measures were deployed to avoid the spread of the disease across to countries of the status quo. According to the World Travel and Tourism Council, tourist arrivals went down by half from 2014 to 2014.

This has necessitated the investigation of the effect of the EVD on trade in West Africa. In this background, the main objective of the study is to estimate the effect of the EVD on trade in West Africa. The specific objective is to estimate the effect of ECOWAS membership on trade in West Africa. To the best of my knowledge, there is no empirical study on the effect of the EVD on trade in West Africa. The existing literature theoretically juxtaposes the effect of the disease in general, on the various variables of interests during the epidemic. This study seeks to estimate the effect of the EVD on trade exports of affected nations to trading partners in the sub-region. Hypothetically, when countries are under trade treaties, there is a greater tendency of trade and movements across countries. In essence, countries are liable to spread diseases as well and necessitate the effect of ECOWAS membership on trade in West Africa since it is the exclusive body to oversee affairs of the sub-region and in support, all affected countries are members. The study will add up to existing literature on EVD on trade and the impact of the ECOWAS on trade in West Africa.

The rest of the paper is organized as follows: the next section provides the theoretical framework, model, and empirical strategy. Section 3 presents the data and measurement. Section 4 presents the results and discussion. The last section concludes the paper with some policy suggestions. 


\section{Literature review}

\subsection{The gravity model of international trade}

In 1962, Tinbergen propounded the gravity model of international trade, with the then of intuition, emanating from the Newton law of gravity. The gravity model of trade intuitively posits that trade between the two countries depends on their economic strength (GDP or GNP) and inversely related to the trade cost. It states that for two countries to trade, it depends on their level of income and the distance between them. The greater the economic mass of the countries coupled with relatively small distances, then countries will tend to trade more and vice versa. It is calculated as the log product of their economic strength divided by the log distance (log values of the trade costs). The theory can be depicted as $X_{i j}=C\left(Y_{i} Y / t_{i j}\right)$, where $X_{i j}=$ trade from $i$ to $j, C$ is the constant, $Y$ is the GDP and $t$ is the distance between the countries. The model has been consistent in its prowess of using real data to determine the sensitivity of trade flows concerning a policy component. The model is used to empirically investigate the effect of trade costs on trade.

It can be used to analyze the trade cost such as tariff and non-tariff barriers, transportation cost, corruption, governance, contract enforcement, regional integration agreement, currency unions, and time delays at export/import, trade facilitation among others.

\section{Empirical literature review}

Adegun (2014) theoretically investigated the effect of the Ebola Virus on the Economy of West Africa through the trade channel using data from the National Bureau of Statistics. The study used graphical representations to explain intraregional imports and exports of affected countries. The study showed that the Ebola Virus will affect the agricultural sector, mining sector, health, transport, education, and hospitality. The study also showed that the resultant effect would have fiscal impacts due to decreased revenue hitherto increased expenditure. The study concludes that if the virus is not highly contained in the short term, its economic repercussion will be devastating to West Africa. Etuk (2015) evaluated the Ebola disease by examining the West Africa perspective with much focus on the virus, affected countries, the role of the populace, West African and Western world responses to the outbreak, and international response notably WHO during the epidemic. Additionally, the study showed that the agricultural sector, health sector, education, and tourism were heavily affected during the epidemic. The study recommended the need for emergency preparedness and public utilities during disease outbreaks. Alexander et al. (2015) examined the possible factors that might have led to the emergence of Ebola in West Africa. The study evaluated the Ebola emergence in the context of why now? And why in West Africa? To expatiate its ecological, sociological, political effect due to the historical implication on the current ameliorated state, and the environmental drivers to the emergence of the virus in line with the effect on humans. Also, the study emphasized the necessary protocols to ensure attenuating the outbreak. Additionally, the study showed that there was an increase in population, poverty, social unrest among others. The study concludes the exigency for prompt disease response in countries with limited resources and recommends the significance of international organizations and Non-governmental Organizations to help curtail the adverse effect of the disease outbreak. Omoleke et al. (2016) evaluated the Ebola Disease in West Africa as a threat to global health, economy, and political stability. The study deployed dataset and information from the WHO library and Information Networks for Knowledge database, PubMed, the Social Science Citation Index, WHO International Clinical Trials Registry Platform, among others. The study acknowledged the role of climate, population growth, economic activities, health, transport, trade, foreign investment among others. The study concluded that human factors notably poverty, weak health system, sanitation challenges, poor health-seeking behavior, climatic change, a change in the ecological system, non-availability of a licensed vaccine among others, enhanced the spread of the disease. The study recommended that governments must be proactive in their commitment to providing quality healthcare facilities to curb any unforeseen health challenges in the future. Maffiola (2018) studied the political economy of health epidemics with a focus on the Ebola outbreak in West Africa. The study sampled out Liberia to evaluate the government response hitherto citizens' reactions to the efforts during the 2014 Ebola outbreak. The reactions of the citizens notably through voting showed if the government was accountable to its citizens. The data used in the study were sourced from the Ministry of Health and Burial teams, ETUs, CCCs, LISGIS, and NEC. The study showed that misplacement of government relief yielded different responses during the general election. The villages that first experienced the outbreak voted against the incumbent government whereas the preceding villages voted in favor. The study concludes that there was a strategic allocation of resources by governments to stimulate the electoral motives of citizens during the health epidemic. Piot et al. (2019) examined the emergent of threats resulting from the lessons learned from Ebola. The study delineated on the political, economic, and health challenges the Ebola disease unraveled on the Economy of West Africa. The study showed that the six lessons learned were; government strengthening its capacity to respond to outbreaks and commensurate domestic and international investment geared towards health 
care, the need for global action across sectors due to the adverse effect of outbreaks beyond borders, implementing standardized control measures to curtail outbreaks with more vigilance and pro-active decisions, the need for research investment into pathogens that causes outbreaks, social responsiveness as a common goal and the need to address pressing needs and indirect behaviors that affect outbreaks.

\section{Methodology}

To investigate the effect of the EVD on trade, the augmented gravity model of international trade was used. The augmented model is stated as follows:

\section{Model 1}

The effect of EBOLA on trade in West Africa

$$
\begin{aligned}
X_{i j}= & \beta_{0} \ln G D P_{i j}+\beta_{1} \ln P E R C A P I T A_{i j}+\beta_{2} \operatorname{lnDISTANCE}_{i j}+\gamma B O R D E R_{i j}+\delta L A N G_{i j}+\theta C O L i j \\
& +\vartheta E B O L A+\beta_{3} \ln G E_{i j}+\beta_{4} \ln V A_{i j}+\beta_{5} \operatorname{Vol}_{i j}+\beta_{6} \ln P S_{i j}
\end{aligned}
$$

\section{Model 2}

The effect of ECOWAS membership on trade in West Africa

$$
\begin{aligned}
X_{i j}= & \beta_{0} \ln G D P_{i j t}+\beta_{l} \ln P E R C A P I T A_{i j t}+\beta_{2} \operatorname{lnDISTANCE} E_{i j}+\lambda B O R D E R_{i j}+\delta L A N G_{i j}+\theta C O L_{i j} \\
& +\beta_{3} I_{N F R A S_{i j t}}+\beta_{4} T A R_{i j t}+\beta_{5} R L_{i j t}+\beta_{6} G E_{i j t}+\beta_{7} V A_{i j t}+\beta_{8} P S_{i j t}+\beta_{9} C C_{i j t}+\sigma E C O W A S_{i j t}
\end{aligned}
$$

where $i$ and $j$ denote countries, $t$ denotes time, and the variables are defined: $X_{i j}$ denotes the value of bilateral trade (exports) between $i$ and $j, Y$ is real GDP, Pop is population, $D_{i j}$ is the distance between $i$ and $j, B O R D E R_{i j}$ is a binary variable which is unity if $i$ and $j$ share a land border, Lang is a binary variable which is unity if $i$ and $j$ have a common official language, $C O L_{i j}$ is a binary variable which is unity if $i$ and $j$ were colonized by the same colonial master, $E C O W A S_{i j}$ is a binary variable which is unity if $i$ and $j$ are members of the ECOWAS and 0 otherwise, $\operatorname{Vol}_{i j}$ is measured as the standard deviation of the moving average of the log Real Effective Exchange Rate (REER), $\varepsilon_{i j}$ a vector of nuisance coefficients, and represents the myriad other influences on bilateral exports, assumed to be well behaved.

Where $I=1,2, \ldots, N$ is the number of countries where $N=16, t$ is the time-series dimension of the data $(T=18$ years), the coefficient $\beta_{1} \beta_{2} \beta_{3} \beta_{4} \beta_{5} \beta_{6} \beta_{7} \beta_{8} \beta_{9}$ are parameters for their respective variables wher $\beta_{0}$ is the constant and $\varepsilon$ is the error term. The coefficient of interest $\vartheta$ and $\sigma$. The coefficient of Ebola is the relevant variable in the first model because not all countries were affected.

\section{Estimation technique}

Although authors recommend estimating the gravity model using a log linearized approach, it is now standard to estimate the AvW model with a fixed effect Poisson Pseudo Maximum Likelihood (PPML) since it controls for heteroscedasticity, zero trade and model misspecification (Gourieroux et al, 1984: Silva Santos and Tenreyro, 2011). Thus, the PPML includes observations with zero trade values of which linear estimation techniques will drop because the logarithm of zero is undefined which leads to sampling selection bias. As a result, the omission of relevant observations poses serious problems, and information is loosed (Eichengreen and Irwin, 1996). Furthermore, the robust standard errors do away with problems associated with panel data estimation. Also, PPML fits the data better by controlling for heteroscedasticity than a log-linear model since the error term has a variance occurring at a higher moment which can be influenced by one or more explanatory variables (Santos Silva and Tenreyro, 2006). Thus, the second and highest moment conditions are absent from the estimation procedure. Therefore, the coefficients of log linearized models can be highly misleading due to the presence of heteroscedasticity. Moreover, the PPML, unlike the log-linear estimator estimates the effect of policy variables on trade whereas the log-linear estimator estimates the policy variable on the log of trade which can be misleading. Additionally, the PPML is consistent with a small sample size as well as a large sample size. To buttress, the Monte Carlo simulation test on the best estimator for the gravity model of international trade stipulates the gravity model is best estimated as a non-linear model (Silva-Santo and Tenreyro, 2006; 2011).

Further studies on the best estimator for the coefficients of the gravity model is the PPML (Bobková, 2012; Martin and Pham, 2015, Vavrek, 2018). Given this, the PPML estimation technique becomes the best option to estimate the parameters.

\section{Data and measurement}

The study used a dataset with 4,320 bilateral trade observations spanning from 2000 to 2017 (some observations are missing for the dependent variable). The study used 16 countries in the West Africa sub-region. A summary of all of 
these variables, how it is defined, measurement and data sources are presented in Table 1. Table A1 in the Appendix presents the variables in the model, description, measurement, and expected signs.

\begin{tabular}{|c|c|c|}
\hline Variables & Measurement & Source \\
\hline Bilateral trade & Export value at levels & IMF Direction of Trade (DOTs) and UN Comtrade \\
\hline GDP & log product of GDP at constant $\$$ & World Bank's World Development Indicators \\
\hline GDP per capita & log product of GDP per capita at constant $\$$ & World Bank's World Development Indicators \\
\hline Distance & log product of distance value between country-pairs & CEPII \\
\hline Tariff & Log product of tariff value & World Bank's ESCAP \\
\hline $\begin{array}{l}\text { Government } \\
\text { effectiveness }\end{array}$ & Log product of values & World Bank's World Governance Indicators \\
\hline $\begin{array}{l}\text { Voice and } \\
\text { Accountability }\end{array}$ & Log product of values & World Bank's World Governance Indicators \\
\hline $\begin{array}{l}\text { Political stability } \\
\text { and absence of } \\
\text { violence }\end{array}$ & Log product of values & World Bank's World Governance Indicators \\
\hline $\begin{array}{l}\text { Trade and } \\
\text { transport } \\
\text { infrastructure }\end{array}$ & Log product of values & World Bank's Logistics Performance \\
\hline Rule of law & Log product of values & World Bank's World Governance Indicators \\
\hline Corruption Control & Log product of values & World Bank's World Governance Indicators \\
\hline Volatility & $\begin{array}{l}\text { The standard deviation of the moving average of log } \\
\text { Real Effective Exchange Rate (REER) }\end{array}$ & $\begin{array}{l}\text { World Bank's World development indictors } \\
\text { and Polity V }\end{array}$ \\
\hline
\end{tabular}

\subsection{Variable definition}

The export of goods was used as a proxy for bilateral trade between the reporting country and the partner in line with each country's attempts to balance its trade with the other. The data on exports were reported at the levels to suit the nonlinear estimation technique procedure. The variable was adopted in the model to represent trade flows between countries since the level of imports is usually underestimated. GDP was used to proxy for the economic mass of the country in the model. The study expected GDP to have a positive relationship with trade. It was measured as the log product of the GDP of country-pairs. GDP per capita was used as a proxy for all other controls that were not specified in the model. The coefficient of GDP per capita used is expected to have a positive relationship with trade. It was measured as the log product of GDP per capita of the country-pairs in the model. Distance is the transportation cost involved in trading between the two countries. The coefficient of distance is expected to have a negative relationship with trade. The higher the transportation cost, the higher the price of the goods to be traded and vice versa. This is because, as distance increases the cost of trading among countries ostensibly increases thereby reducing the volume of trade. GDP per capita was used as a control variable for the effect of institutions on trade to represent market size based on theory. This paper employs five different key indicators of institutional quality as provided by the World Governance Indicators, WGI (2019) database namely; rule of law, voice and accountability, political stability and Absence of Violence, control of corruption and government effectiveness. Rule of Law captures perceptions of the extent to which agents have confidence 
in and abide by the rules of society, and in particular the quality of contract enforcement, property rights, the police, and the courts, as well as the likelihood of crime and violence.

Also, the control of corruption was captured as the perception of the extent to which public power is exercised for private gain, including both petty and grand forms of corruption, as well as the capture of the state by elites and private interests. Furthermore, government effectiveness captures perceptions of the quality of public services, the quality of the civil service and the degree of its independence from political pressures, the quality of policy formulation and implementation, and the credibility of the government's commitment to such policies.

Voice and accountability as defined by WGI, voice and accountability captures perceptions of the extent to which a country's citizens can participate in selecting their government, as well as freedom of expression, freedom of association, and a free media. Finally, political stability and absence of violence/terrorism measures perceptions of the likelihood of political instability and/or politically-motivated violence, including terrorism. The various indicators of institutions were measured as the log product of the country-pairs. Tariff is defined as the taxes charged on goods and services imported. According to the World Bank ESCAP, Tariff answers the question, 'Evaluate the effect of tariffs about agricultural goods.' The coefficient of tariff is expected to harm trade. It was measured as the log of the value for the country-pairs. According to the World Bank Logistics Performance Index, the component "Quality of trade- and transport-related infrastructure" includes results from the survey question "Evaluate the quality of trade and transport-related infrastructure (e.g., ports, railroads, roads, information technology) in-country. The coefficient is expected to have a positive impact on trade. It was measured as the log product of the country-pairs. REER as computation of exchange rate volatility due to recent developments in academia (Serenis and Tsuonis, 2014).

Border is defined as the geographic boundaries of political entities such as countries, provinces, states amongst others. The coefficient of sharing a land border is expected to have a positive relationship with trade. Spatial theory of trade depicts that countries sharing border tends to cooperate to enhance trade. The coefficient of Language is expected to have a positive relationship with trade. Adam Smith argued in 'Wealth of Nations' that common language enhances trade and exchange through effectively communicating the task in hand to the trading partners and easily convincing parties to know it is in their best interest.

\subsection{Modeling the effect of disease on trade}

The traditional determinants of trade are GDP, distance, border, common language, and common colonizer. Variables such as Government Effectiveness, Political Stability and Absence of Violence, and Voice and Accountability were introduced into the model. The rationale for these variables is as follows; Disasters are a unique test of governmental accountability (Maffioli, 2018). Also, governments have the opportunity to influence voters, through their responsiveness to crises on how well they can perform. Therefore Government Effectiveness was a good proxy for the model. On the other hand, citizens have a chance to learn about the incumbent government's capacity and thus ensure electoral accountability at the time of voting (Maffioli, 2018). Therefore, Voice and Accountability was a good proxy for the populace. Additionally, the disease outbreak aroused anger and violence of the populace against their respective governments and traditional leaders, therefore, Political Stability and Absence of Violence was a good proxy (Foucault, 1975; Camus, 1991; Price-Smith, 2008; Woldemariam and Di Giacomo, 2016; Omoleke et al., 2016). Trade and transport infrastructure were affected during the Ebola epidemic due to increased price hitherto limited distance coverage resulting from restrictions (AGOA, 2015). Therefore the quality of trade and transport infrastructure was a good proxy. Additionally, the decline in economic activities will affect currency performance which would increase the cost of international trade. In this context, exchange rate volatility was introduced in the model. Therefore, understanding the efficacy of and motives behind the response to disasters is of paramount policy relevance to provide the right incentives for governments to act appropriately in times of crisis (Maffioli, 2018). Foreign Direct Investment inflow was excluded because its inclusion did not improve the model. However, in regions where FDI inflow has a significant effect on trade, there is a need to add FDI inflow to improve the model.

\subsection{Modeling the Ebola disease in the gravity model of international trade}

The essential factors in the modeling of the disease are the period of occurrence, the affected countries, capturing period ex-ante and ex-post of the disease, and the intra-regional importers of the exports of the affected countries (trading partners in West Africa) since export will dwindle. Using annual data, weight is given to the number of months the disease was prevalent, and its intensity. The period (year) before and after the disease is assigned as 1 . The period (year) that the disease affects trade volume of the affected country to trading partners is assigned as 0.

\section{Empirical results and discussion}

The coefficient of Ebola is found to be negative with an estimated coefficient of -1.705 and statistically significant at $1 \%$. The results show that the EVD reduced intra-trade exports of affected countries to its partners by two folds, all else equal. This is not startling because the three most affected countries were on the verge of collapse hither to economic growth dwindled (Adegun, 2014; Etuk, 2015; AfDB, 2019). 
The coefficient of ECOWAS was positive with a coefficient of 2 and significant at $1 \%$. The result shows that ECOWAS membership doubles the level of trade of members in West Africa. This is not startling because regional trade agreement stimulates trade flows of member-states by eliminating some barriers to trade. Additionally, the ECOWAS had been a voice in ensuring political and economic sustainability, to ensure growth in the sub-region.

\begin{tabular}{|c|c|}
\hline Variables & Coefficients \\
\hline GDP & $\begin{array}{l}2.584 * * \\
(1.02938)\end{array}$ \\
\hline GDP per capita & $\begin{array}{c}2.216 \\
(1.80155)\end{array}$ \\
\hline Distance & $\begin{array}{c}-0.004 * * * \\
(0.00075)\end{array}$ \\
\hline Border & $\begin{array}{l}2.049 * * \\
(0.97033)\end{array}$ \\
\hline Language & $\begin{array}{c}-0.233 \\
(1.55074)\end{array}$ \\
\hline Colonizer & $\begin{array}{c}0.710 \\
(1.77221)\end{array}$ \\
\hline Ebola & $\begin{array}{r}-1.705 * * * \\
(0.52164)\end{array}$ \\
\hline Infrastructure & $\begin{array}{c}-12.712 * * \\
(0.011)\end{array}$ \\
\hline Government effectiveness & $\begin{array}{c}-2.291 \\
(2.54357)\end{array}$ \\
\hline Voice and accountability & $\begin{array}{l}4.661 * * * \\
(1.20326)\end{array}$ \\
\hline Volatility & $\begin{array}{c}3.056 \\
(3.10247)\end{array}$ \\
\hline Political Stability and Absence of Violence & $\begin{array}{c}3.760 \\
(1.34177)\end{array}$ \\
\hline _cons & $\begin{array}{c}-35.891 * * \\
(15.6177)\end{array}$ \\
\hline
\end{tabular}




\begin{tabular}{|c|c|}
\hline Variables & Coefficients \\
\hline GDP & $\begin{array}{c}0.849 * * \\
(0.3962187)\end{array}$ \\
\hline GDP per capita & $\begin{array}{c}1.630 * \\
(0.9239736)\end{array}$ \\
\hline Distance & $\begin{array}{c}-0.001 * * \\
(0.0003867)\end{array}$ \\
\hline Border & $\begin{array}{c}-0.0405 \\
(0.3686981)\end{array}$ \\
\hline Language & $\begin{array}{c}-0.429 \\
(0.7932172)\end{array}$ \\
\hline Colonizer & $\begin{array}{c}1.157 \\
(0.7311446)\end{array}$ \\
\hline Infrastructure & $\begin{array}{c}0.578 \\
(0.9158292)\end{array}$ \\
\hline Tariff & $\begin{array}{c}0.482 \\
(0.3561939)\end{array}$ \\
\hline RL & $\begin{array}{c}0.655 \\
(0.563937)\end{array}$ \\
\hline GE & $\begin{array}{c}0.182 \\
(0.8081201)\end{array}$ \\
\hline VA & $\begin{array}{c}-0.055 \\
(0.3405651)\end{array}$ \\
\hline PS & $\begin{array}{c}-0.019 \\
(0.2437592)\end{array}$ \\
\hline $\mathrm{CC}$ & $\begin{array}{c}-0.047 \\
(0.1645486)\end{array}$ \\
\hline ECOWAS & $\begin{array}{c}2.004 * * * \\
(0.7588316)\end{array}$ \\
\hline _cons & $\begin{array}{l}-11.605 * * \\
(4.859767)\end{array}$ \\
\hline
\end{tabular}




\section{Policy Recommendation and Conclusion}

The analysis shows that the variables of interests have a significant effect on trade in West Africa. In this context, the study showed that the EVD reduced trade export shares of affected countries to their intra-regional partners by two folds. The study also showed that ECOWAS membership doubled the level of trade. Ebola was found to have a negative and statistically significant effect on trade in West Africa. In a nutshell, poor regions are most likely to have a greater repercussion on trade hence economic growth when there is an outbreak. In this background, the study recommends that there should be proactive measures towards the potential outbreak of disease by ensuring good sanitation and personal hygiene as well as the preservation of natural habitats through education. Also, hotspots of reported outbreaks should be well broadcasted to ensure stringent measures are taken in areas of the status quo. More so, since the duration of symptoms for most viruses is two to three weeks, there is a need for a month nationwide lockdown with caveats for food suppliers. Furthermore, the notification of an outbreak in any part of the world should signal the implementation of stringent measures at the entry point of countries. In this context, travelers are to be quarantined for a month before allowed to enter the country as a policy variable. Also, evaluating the risk of spread on a national basis to flatten the curve of the spread. Additionally, the ECOWAS should invest more in medical research with herbal drugs inclusive and a potential vaccine for virus-related diseases. Also, countries should initiate on the spot fine of culprits that will incentivize the government and the reporter of the culprits. The ECOWAS membership was found to have a positive and significant effect on trade in West Africa. Therefore, ECOWAS should be proactive in ensuring a sound political and economic environment by improving upon the trade and transport infrastructure specifically railway due to the topography of the land and a relatively cheaper and faster means of transport. Also, the ECOWAS should attenuate the effect of any notable trade barriers to stimulate further trade. Additionally, a medical test result of at least three weeks should be stipulated and emphasized criteria before travelling from one country to another within the sub-region. The study also recommends that there is a relatively greater incentive for Mauritania in rejoining the ECOWAS as compared to its current membership in the Arab Maghreb Union (AMU).

\section{References}

Alexander, K.A., Sanderson, C.E., Marathe, M., Lewis, B.L., Rivers, C.M., Shaman, J., Drake, J.M., Lofgren, E., Dato, V.M., Eisenberg, M.C. and Eubank, S., (2015). What factors might have led to the emergence of Ebola in West Africa?. PLoS Negl Trop Dis, 9(6), e0003652.

Adegun, O. (2014). The effects of Ebola virus on the economy of West Africa through the trade channel. IOSR Journal of Humanities and Social Science (IOSR-JHSS). 19, 48-56.

Althaus, C.L., Low, N., Musa, E.O., Shuaib, F. and Gsteiger, S. (2015). Ebola virus disease outbreak in Nigeria: transmission dynamics and rapid control. Epidemics. 11, 80-84.

Ajiboye, O., Rotimi, J. and Sumaila, A.F. (2015). Transport factor in the spread of Ebola and the building of disaster risk management capacity in West Africa. Journal of Transport \& Health, 2(2), S77.

Adam Kamradt-Scott (2016). WHOs to blame? The World Health Organization and the 2014 Ebola outbreak in West Africa, Third World Quarterly, 37:3, 401-418, DOI: 10.1080/01436597.2015.1112232

African Union and WHO. (2014). Establishment of an African Centre for Disease Control and Preventionâ AUC/WHO/ 2014/Doc. 5, 19 March 2014.

Anderson, J.E. (2011). The gravity model. Annu. Rev. Econ. 3(1), 133-160.

Ajisegiri, W.S., Chughtai, A.A. and MacIntyre, C.R. (2018). A risk analysis approach to prioritizing epidemics: ebola virus disease in West Africa as a case study. Risk Anal. 38, 429-441. doi: 10.1111/risa.12876

Bell, B.P. (2016). Overview, control strategies, and lessons learned in the CDC response to the 2014-2016 Ebola epidemic. MMWR supplements. 65.

Baize, S., Pannetier, D., Oestereich, L., Rieger, T., Koivogui, L., Magassouba, N.F., Soropogui, B., Sow, M.S., Keïta, S., De Clerck, H. and Tiffany, A. (2014). Emergence of Zaire Ebola virus disease in Guinea. New England Journal of Medicine.371(15), 1418-1425.

Breman, J.G., Heymann, D.L., Lloyd, G., McCormick, J.B., Miatudila, M., Murphy, F.A., Muyembé-Tamfun, J.J., Piot, P., Ruppol, J.F., Sureau, P. and van der Groen, G. (2016). Discovery and description of Ebola Zaire virus in 1976 and relevance to the West African epidemic during 2013-2016. The Journal of infectious diseases, 214(suppl_3), S93S101.

Brolin Ribacke, K.J., Saulnier, D.D., Eriksson, A. and Von Schreeb, J. (2016). Effects of the West Africa Ebola virus disease on health-care utilization-a systematic review. Frontiers in public health. 4, 222. 
Burd, E.M. (2015). Ebola virus: a clear and present danger. Journal of clinical microbiology. 53(1), 4-8.

Bogoch, I.I., Creatore, M.I., Cetron, M.S., Brownstein, J.S., Pesik, N., Miniota, J., Tam, T., Hu, W., Nicolucci, A., Ahmed, S. and Yoon, J.W. (2015). Assessment of the potential for international dissemination of Ebola virus via commercial air travel during the 2014 west African outbreak. The Lancet. 385(9962), 29-35.

Bowles, J., Hjort, J., Melvin, T. and Werker, E. (2016). Ebola, jobs and economic activity in Liberia. J Epidemiol Community Health. 70(3), 271-277.

Bobková, B. (2012). Gravity model estimation using panel data-is logarithmic transformation advisable?

Centers for Disease Control and Prevention (2014). Ebola outbreak in West Africa-case counts. http://www. cdc. gov/ vhf/ebola/o utbreaks/2014-west-africa/casecounts. html. Acesso em, 8(12), 2014.

Cori, A., Donnelly, C.A., Dorigatti, I., Ferguson, N.M., Fraser, C., Garske, T., Jombart, T., Nedjati-Gilani, G., Nouvellet, P., Riley, S. and Van Kerkhove, M.D. (2017). Key data for outbreak evaluation: building on the Ebola experience. Philosophical Transactions of the Royal Society B: Biological Sciences, 372(1721), 20160371.

CDC. (2014). Ebola (Ebola virus disease) Atlanta, GA: US Department of Health and Human Services, CDC (2014). Available at http://www.cdc.gov/vhf/ebola. [Google Scholar]

Cenciarelli, O., Pietropaoli, S., Malizia, A., Carestia, M., D’ Amico, F., Sassolini, A., Di Giovanni, D., Rea, S., Gabbarini, V., Tamburrini, A. and Palombi, L. (2015). Ebola virus disease 2013-2014 outbreak in west Africa: an analysis of the epidemic spread and response. International journal of microbiology.

Center for Disease Control and Prevention. Treatment URL: https://www.cdc.gov/vhf/ebola/treatment/ [accessed 201803-29] [WebCite Cache]

Center for Disease Control and Prevention. Implementation and management of contact tracing for Ebola virus disease URL: https://www.cdc.gov/vhf/ebola/pdf/contact-tracing-guidelines.pdf [accessed 2018-03-29] [WebCite Cache]

Etuk, E.E. (2015). Ebola: a West African perspective. JR Coll Physicians Edinb. 45(1), 19-22.

Epstein, H. (2014). Ebola in Liberia: An epidemic of rumors. New York Review of Books, 61(20), 91-+.

Fasina, F.O., Shittu, A., Lazarus, D., Tomori, O., Simonsen, L., Viboud, C. and Chowell, G. (2014). Transmission dynamics and control of Ebola virus disease outbreak in Nigeria, July to September 2014. Eurosurveillance, 19(40), $209-220$.

Ferrel, C. and Agarwal, P. (2018). Flight Bans and the Ebola Crisis: Policy Recommendations for Future Global Health Epidemics. Harvard Public Health Review.

Foucault, M. (1975). Surveiller et punir. Paris, 1, 192-211.

Camus, A. (1991). Between Hell and Reason: Essays from the Resistance Newspaper Combat, 1944-1947. Wesleyan University Press.

Gomes, M.F., y Piontti, A.P., Rossi, L., Chao, D., Longini, I., Halloran, M.E. and Vespignani, A. (2014). Assessing the international spreading risk associated with the 2014 West African Ebola outbreak. PLoS currents. 6.

Goeijenbier, M., Van Kampen, J.J., Reusken, C.B., Koopmans, M.P. and Van Gorp, E.C. (2014). Ebola virus disease: a review on epidemiology, symptoms, treatment and pathogenesis. Neth J Med, 72(9), 442-8.

Gostin, L.O. and Friedman, E.A. (2015). A retrospective and prospective analysis of the west African Ebola virus disease epidemic: robust national health systems at the foundation and an empowered WHO at the apex. The Lancet, 385(9980), 1902-1909.

Grépin, K.A. (2015). International donations to the Ebola virus outbreak: too little, too late?. Bmj. 350.

Gourieroux, C., Monfort, A. and Trognon, A. (1984). Pseudo maximum likelihood methods: Theory. Econometrica: journal of the Econometric Society. 681-700.

Global Alert Response EVD: Democratic Republic of Congo. www.who.int/csr/don/2014_09_10_ebola/en/ WHO. 2015a. Global Alert and Response (GAR) One year into the Ebola epidemic: a density, tenacious and unforgiving virus. January 2015. www. who.int/csr/disease/ebola/one-year-report/introduction/en/

Isakov, A., Miles, W., Gibbs, S., Lowe, J., Jamison, A. and Swansiger, R. (2015). Transport and management of patients with confirmed or suspected Ebola virus disease. Annals of emergency medicine. 66(3), 297-305.

Judson, S.D., Fischer, R., Judson, A. and Munster, V.J. (2016). Ecological contexts of index cases and spillover events of different ebolaviruses. PLoS pathogens. 12(8), p.e1005780. 
Joshi, R.M. (2014). Ebola virus disease (EVD): an unprecedented major outbreak in West Africa. Clinical Microbiology: Open Access.

Kamradt-Scott, A. (2016). WHO's to blame? The World Health Organization and the 2014 Ebola outbreak in West Africa. Third World Quarterly. 37(3), 401-418.

Kadanali, A. and Karagoz, G. (2015). An overview of Ebola virus disease. Northern clinics of Istanbul. $2(1), 81$.

Kerstiëns, B. and Matthys, F. (1999). Interventions to control virus transmission during an outbreak of Ebola hemorrhagic fever: experience from Kikwit, Democratic Republic of the Congo, 1995. The Journal of infectious diseases. 179(Supplement_1), S263-S267.

Kalra, S., Kelkar, D., Galwankar, S.C., Papadimos, T.J., Stawicki, S.P., Arquilla, B., Hoey, B.A., Sharpe, R.P., Sabol, D. and Jahre, J.A. (2014). The emergence of ebola as a global health security threat: from 'lessons learned' to coordinated multilateral containment efforts. Journal of global infectious diseases. 6(4), 164.

Kadanali, A. and Karagoz, G. (2015). An overview of Ebola virus disease. Northern clinics of Istanbul. $2(1), 81$.

Kaasik-Aaslav, K. and Coulombier, D. (2015). The tail of the epidemic and the challenge of tracing the very last Ebola case. Eurosurveillance, 20(12), 210-275.

Kramer, A.M., Pulliam, J.T., Alexander, L.W., Park, A.W., Rohani, P. and Drake, J.M. (2016). Spatial spread of the West Africa Ebola epidemic. Royal Society open science, 3(8), 160-294.

Madariaga, M.G. (2015). Ebola virus disease: a perspective for the United States. The American journal of medicine. 128(7), 682-691.

Mobula, L.M., Nakao, J.H., Walia, S., Pendarvis, J., Morris, P. and Townes, D. (2018). A humanitarian response to the West African Ebola virus disease outbreak. Journal of International Humanitarian Action, 3(1), 1-6.

Maphanga, P.M. and Henama, U.S. (2019). The tourism impact of Ebola in Africa: Lessons on crisis management. African Journal of Hospitality, Tourism and Leisure, 8(3), 1-13.

Malvy, D., McElroy, A.K., de Clerck, H., Günther, S. and van Griensven, J. (2019). Ebola virus disease. The Lancet. 393(10174), 936-948.

Maffioli, E.M. (2018). The political economy of health epidemics: evidence from the Ebola outbreak. Available at SSRN 3383187.

Martin, W. and Pham, C.S. (2020). Estimating the gravity model when zero trade flows are frequent and economically determined. Applied Economics, 52(26), 2766-2779.

Owada, K., Eckmanns, T., Kamara, K.B.O.B. and Olu, O.O. (2016). Epidemiological data management during an outbreak of Ebola virus disease: key issues and observations from Sierra Leone. Frontiers in public health, 4, 163.

Omoleke, S.A., Mohammed, I. and Saidu, Y. (2016). Ebola viral disease in West Africa: a threat to global health, economy and political stability. Journal of public health in Africa, 7(1).

Piot, P., Soka, M.J. and Spencer, J. (2019). Emergent threats: lessons learnt from Ebola. International health. 11(5), 334337.

Peters, C.J. and Peters, J.W. (1999). An introduction to Ebola: the virus and the disease. The Journal of Infectious Diseases. 179(Supplement_1), ix-xvi.

Price-Smith, A.T. (2008). Contagion and chaos: disease, ecology, and national security in the era of globalization. MIT press.

Pan American Health Organization / World Health Organization. Preparedness and Response for introduction of Ebola virus disease (EVD) in the Americas. Washington, D.C.: PAHO/WHO, 2014. http://www.paho.org/hq/ index.php?option=com_docman\&task=doc_download\&Itemi d=\&gid=27454\&lang=en

Rosello, A., Mossoko, M., Flasche, S., Van Hoek, A.J., Mbala, P., Camacho, A., Funk, S., Kucharski, A., Ilunga, B.K., Edmunds, W.J. and Piot, P. (2015). Ebola virus disease in the Democratic Republic of the Congo, 1976-2014. Elife. 4, e09015.

Redding, D. W., Atkinson, P. M., Cunningham, A. A., Iacono, G. L., Moses, L. M., Wood, J. L. and Jones, K. E. (2019). Impacts of environmental and socio-economic factors on emergence and epidemic potential of Ebola in Africa. Nature communications. 10(1), 1-11. 
Singh, R.K., Dhama, K., Malik, Y.S., Ramakrishnan, M.A., Karthik, K., Khandia, R., Tiwari, R., Munjal, A., Saminathan, M., Sachan, S. and Desingu, P.A. (2017). Ebola virus-epidemiology, diagnosis, and control: threat to humans, lessons learnt, and preparedness plans-an update on its 40 year's journey. Veterinary Quarterly, 37(1), 98-135.

Simeon Ajisegiri, W., Chughtai, A.A. and MacIntyre, C. (2017). A Risk Analysis Approach to Prioritizing Epidemics: Ebola Virus Disease in West Africa as a Case Study.

Salaam-Blyther, T., (2014). The 2014 Ebola Outbreak: International and US Responses (26). Congressional Research Service.

Shuaib, F., Gunnala, R., Musa, E.O., Mahoney, F.J., Oguntimehin, O., Nguku, P.M., Nyanti, S.B., Knight, N., Gwarzo, N.S., Idigbe, O. and Nasidi, A. (2014). Ebola virus disease outbreak-Nigeria, July-September 2014. MMWR. Morbidity and mortality weekly report. 63(39), 867.

Silva, J.S. and Tenreyro, S. (2011). Further simulation evidence on the performance of the Poisson pseudo-maximum likelihood estimator. Economics Letters. 112(2), 220-222.

Silva, J.S. and Tenreyro, S. (2006). The log of gravity. The Review of Economics and statistics. 88(4), 641-658.

Serenis, D. and Tsounis, N. (2014). Does Exchange Rate Variation Effect African Trade Flows? Procedia Economics and Finance. 14, 565-574.

Tseng, C.P. and Chan, Y.J. (2015). Overview of Ebola virus disease in 2014. Journal of the Chinese Medical Association. 78(1), 51-55.

UNDG-WCA. (2015). Socio-Economic Impact of the Ebola Virus Disease in West African Countries: A call for National and Regional Containment, Recovery and Prevention, United Nations Development Group for Western and Central Africa UN-OCHA (2014) Ebola Virus Outbreak WEST AFRICAApril2014. Available: http://fts.unocha.org/ pageloader.aspx?page=emergemergencyDetails\&emergID=16506 Accessed 22 October 2014.

UN. (2014). National Study on the Socio-economic Impacts of the Epidemic of Ebola fever in Guinea, A Draft Report, Guinea United Nations System, December 2014.

United Nations Office of High Commissioner for Human Rights (OHCHR) West African Region Office (WARO). (2015). A human rights perspective into the Ebola Outbreak TM, February 2015. UNOCHA. 2014a.

UNOCHA Financial Tracking Services on the Ebola outbreak (2014). http://fts.unocha.org/ [accessed on 22 October 2014].

UNOCHA. (2014b). United Nations Ebola Virus Disease Outbreak: Overview of Needs and Requirements, September 2014.

Vavrek, Š. (2018). of Thesis: Estimation methods of gravity models. International Economics. 40(1-2), 23-39.

Woldemariam, Y. and Giacomo, L.D. (2016). Ebola epidemic. ASPJ: Africa and Francophonie. 7(1), 54-72.

Wagenaar, B.H., Augusto, O., Beste, J., Toomay, S.J., Wickett, E., Dunbar, N., Bawo, L. and Wesseh, C.S. (2018). The 2014-2015 Ebola virus disease outbreak and primary healthcare delivery in Liberia: Time-series analyses for 2010 2016. PLoS medicine. 15(2), e1002508.

World Bank Group (2014). The economic impact of the 2014 Ebola epidemic: short and medium term estimates for West Africa (World Bank Group).

World Health Organization (2014). Clinical Management of Patients with Viral Hemorrhagic Fever: A Pocket Guide for the Front-line Health Worker. Geneva. http://www.who.int/entity/csr/resources/publications/clinical-managementpatients/e n/index.html World Health Organization.

World Health Organization (2015b). Situation summary by sex and age group, http://apps. who.int/gho/data/view.ebolasitrep. ebola-summary-age-sex-20150107?lang=en World Bank. 2014. The Economic Impact of the 2014 Ebola Epidemic: Short- and Medium-Term Estimates for West Africa. Washington, DC.

World Health Organization (2016). Statement on the 9th meeting of the IHR Emergency Committee regarding the Ebola outbreak in West Africa. 29 March, 2016. http://www.who.int/mediacentre/news/statements/2016/end-of-ebolapheic/en/. Accessed 15 Aug 2016. 


\section{Appendix}

\begin{tabular}{|c|c|c|c|c|c|c|}
\hline \multicolumn{7}{|c|}{ The Effect of Ebola on trade } \\
\hline \multicolumn{7}{|c|}{ Number of parameters: 13} \\
\hline \multicolumn{7}{|c|}{ Number of observations: 123} \\
\hline \multicolumn{7}{|c|}{ Number of observations dropped: 0} \\
\hline \multicolumn{7}{|c|}{ Pseudo log-likelihood: $-1.677 \mathrm{e}+09$} \\
\hline \multicolumn{4}{|c|}{ R-squared: 0.96067316} & \multicolumn{3}{|c|}{ (Std. Err. adjusted for 32 clusters in pairings) } \\
\hline trade & Coef. & $\begin{array}{l}\text { Robust } \\
\text { Std. Err. }\end{array}$ & $z$ & $P>|z|$ & {$[95 \% \mathrm{C}$} & if. Interval] \\
\hline $\operatorname{lnGDP}$ & 2.583855 & 1.029384 & 2.51 & 0.012 & 0.5662989 & 4.601412 \\
\hline lnpercapita & 2.216443 & 1.801548 & 1.23 & 0.219 & -1.314526 & 5.747413 \\
\hline lndistance & -0.003814 & 0.0007524 & -5.07 & 0.000 & -0.0052888 & -0.0023393 \\
\hline border & 2.049413 & 0.9703325 & 2.11 & 0.035 & 0.147596 & 3.95123 \\
\hline lang & -0.2334202 & 1.55074 & -0.15 & 0.880 & -3.272814 & 2.805974 \\
\hline colonizer & 0.7095882 & 1.772207 & 0.40 & 0.689 & -2.763874 & 4.18305 \\
\hline Ebola & -1.704759 & 0.521639 & -3.27 & 0.001 & -2.727152 & -0.6823652 \\
\hline infrastructure & -12.71167 & 5.017295 & -2.53 & 0.011 & -22.54539 & -2.877952 \\
\hline GE & -2.291091 & 2.543568 & -0.90 & 0.368 & -7.276393 & 2.694212 \\
\hline VA & 4.660808 & 1.203261 & 3.87 & 0.000 & 2.30246 & 7.019156 \\
\hline volatlity & 3.055929 & 3.102469 & 0.98 & 0.325 & -3.024799 & 9.136657 \\
\hline PS & 3.760022 & 1.341768 & 2.80 & 0.005 & 1.130205 & 6.38984 \\
\hline _cons & -35.89109 & 15.61771 & -2.30 & 0.022 & -66.50123 & -5.280954 \\
\hline
\end{tabular}

\section{The Effect of ECOWAS membership on trade in West Africa}

Number of parameters: 15

Number of observations: 363

Number of observations dropped: 0

Pseudo log-likelihood: $-1.902 \mathrm{e}+09$

R-squared: 0.53173236

(Std. Err. adjusted for 32 clusters in pairings)

\begin{tabular}{l|c|c|c|c|c|c|}
\hline trade & Coef. & $\begin{array}{c}\text { Robust } \\
\text { Std. Err. }\end{array}$ & $z$ & $P>|z|$ & \multicolumn{2}{|c}{ [95\% Conf. Interval] } \\
\hline InGDP & 0.8491892 & 0.3962187 & 2.14 & 0.032 & 0.0726148 & 1.625764 \\
Inpercapita & 1.629767 & 0.9239736 & 1.76 & 0.078 & -0.1811875 & 3.440722 \\
lndistance & -0.0008047 & 0.0003867 & -2.08 & 0.037 & -0.0015626 & -0.0000468 \\
border & -0.0404739 & 0.3686981 & -0.11 & 0.913 & -0.7631089 & 0.6821611 \\
lang & -0.4294525 & 0.7932172 & -0.54 & 0.588 & -1.98413 & 1.125225 \\
colonizer & 1.156959 & 0.7311446 & 1.58 & 0.114 & -0.2760577 & 2.589977 \\
infrastructure & 0.5782084 & 0.9158292 & 0.63 & 0.528 & -1.216784 & 2.373201 \\
Tariff & 0.4815705 & 0.3561939 & 1.35 & 0.176 & -0.2165567 & 1.179698 \\
RL & 0.6551379 & 0.563937 & 1.16 & 0.245 & -0.4501584 & 1.760434 \\
GE & 0.1817317 & 0.8081201 & 0.22 & 0.822 & -1.402155 & 1.765618 \\
VA & -0.0554966 & 0.3405651 & -0.16 & 0.871 & -0.722992 & 0.6119987 \\
PS & -0.0189212 & 0.2437592 & -0.08 & 0.938 & -0.4966805 & 0.458838 \\
CC & -0.0471887 & 0.1645486 & -0.29 & 0.774 & -0.369698 & 0.2753206 \\
ECOWAS & 2.004066 & 0.7588316 & 2.64 & 0.008 & 0.5167831 & 3.491348 \\
cons & -11.60545 & 4.859767 & -2.39 & 0.017 & -21.13042 & -2.080483 \\
\hline
\end{tabular}

Cite this article as: A bban, Stanley (2021). The effect of the Ebola Virus Disease on intra-regional tradein West Africa. International Journal of M anagement Research and Economics. 1(2), 18-32. doi: 10.51483/ IJMRE.1.2.2021.18-32. 